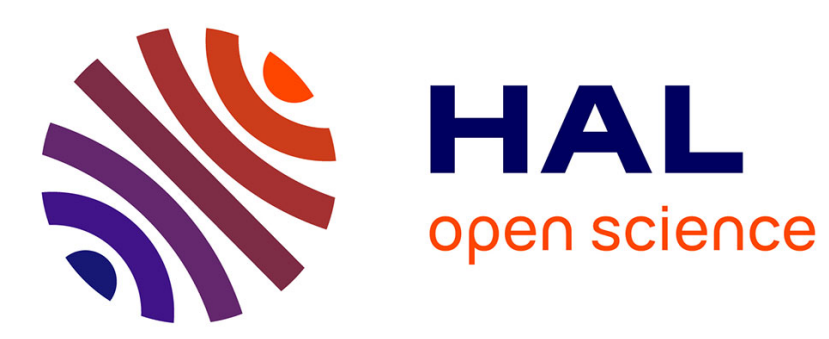

\title{
Jules Dupuit and the railroads: what is the role of the State? \\ Philippe Poinsot
}

\section{To cite this version:}

Philippe Poinsot. Jules Dupuit and the railroads: what is the role of the State?. Journal of the History of Economic Thought, 2016, 38 (2), 10.1017/S1053837216000080 . hal-01383443

\section{HAL Id: hal-01383443 https://hal.science/hal-01383443}

Submitted on 22 Aug 2019

HAL is a multi-disciplinary open access archive for the deposit and dissemination of scientific research documents, whether they are published or not. The documents may come from teaching and research institutions in France or abroad, or from public or private research centers.
L'archive ouverte pluridisciplinaire HAL, est destinée au dépôt et à la diffusion de documents scientifiques de niveau recherche, publiés ou non, émanant des établissements d'enseignement et de recherche français ou étrangers, des laboratoires publics ou privés. 


\title{
JULES DUPUIT AND THE RAILROADS: WHAT IS THE ROLE OF THE STATE?
}

\begin{abstract}
The emergence of railroads in France in the nineteenth century gave rise to new debates on analytical issues. The focus of interest lay in the fact that they are natural monopolies. In this paper, I focus on Jules Dupuit's work on the operations of the railroad sector. Curiously, he seemed to have defended two contrasting positions, opening the way for debate among commentators: on the one hand, he claimed that unlimited competition is the most efficient way to operate in the railroad sector; on the other, he stated that State management was the best way to run the railroads. I aim to restore the consistency of Dupuit's positions on the railroads. In section II, I discuss Dupuit's position on unlimited competition in the railroad sector, showing that, for him, this kind of competition is not possible in the railroads and that it is not necessarily good for the welfare of society. Therefore, the State should regulate the railroad sector either by State management or through concessions. In section III, I specify the conditions under which Dupuit believed the State should manage the railroad sector instead of offering concessions to private companies.
\end{abstract}

Keywords: railroads, Jules Dupuit, natural monopoly, regulation, competition

J.E.L. Classification: B10, D42, L51, L92.

\section{INTRODUCTION}

Jules Dupuit always regarded transportation as a driving force for the wealth and welfare of society. By lowering the effective distance between consumers and the goods which satisfy their needs, enhanced transportation increases trade and decreases the price of goods (see, for instance, Dupuit, 1853a, pp. 431-2). Although he discussed all the means of transportation (ship canals, roads and railroads), there are four reasons to emphasize his position concerning the railroad industry. First, Dupuit believed that the development of the railroad industry would have important consequences for society at the political, economic and social 
level (Dupuit 1863a, p. 488). He even compared this means of transportation with inventions such as the compass and printing (Ibid., p. 484). Second, as remarked by Alain Béraud (2005a, p. 19), the emergence of railways brought with it new issues in comparison with other means of transport: their operations require a higher degree of coordination between companies than in other means of transportation, and, for him, this made vertical separation impossible in practice. ${ }^{1}$ Third, the railroads are a good example of how Dupuit considered that the State should function with respect to society. Government intervention should be determined on the basis of an impartial criterion: "public utility". Fourthly, the railways afford us an opportunity to discuss Walras's criticisms of Dupuit's position concerning the optimal mode of operation for the railroads, which Walras considered to be inconsistent. On this particular point, Dupuit discussed three modes of operation: private monopoly (or concession ${ }^{2}$ ), government operation, and unlimited competition.

On the one hand, Dupuit claimed that State management was the best way to run the railroads because they are "natural monopolies"3 (1862a, pp. 588-9), and because "railroads... do not lend themselves to [unlimited] competition" (Ibid., p. 589), adding that:

\footnotetext{
"Private companies are overseen... by an army of civil servants, so that we can wonder whether an industry, which can only work in these conditions, would not better be operated by State. We do not see any economic principle against this solution..." (Ibid., p. 585).
}

On the other hand, however, Dupuit stated that unlimited competition is the most efficient way to operate in the railroad sector (Robert B. Ekelund \& Robert F. Hébert 1999, p. 669, footnote no. 24; Guy Numa 2012, p. 79). For instance, he wrote that

\footnotetext{
${ }^{1}$ According to Dupuit, vertical unbundling is impossible because it entails safety problems (see infra, section II.2, p. 8).

${ }^{2}$ In section III (p. 17), I will show that Dupuit's arguments could be applied to concessionaires as well as nonprivate companies which are not concessionaires.

${ }^{3}$ Only two articles by Dupuit have been translated into English: "On the measurement of the utility of public works" and "On Tolls and Transport Charges". With regard to the texts for which there is no translation, most of the time I offer my own translation. But in some particular cases I appeal to either Ekelund \& Hébert's (1999, 2012) or Numa's translations (2012).
} 


\begin{abstract}
"yet there would be another way to take this industry [the railroads] away from State control: it would be to acknowledge... complete competition and complete freedom. This may be the true economic solution" (1853a, p. 450; my italics).
\end{abstract}

While the topic of railroads in Dupuit's thought has given rise to extensive discussion in the literature, the consistency of his position has never formed the central issue of the debate.

According to Ekelund and Hébert, "Dupuit... identified a natural monopoly argument with respect to the railroad" (1999, pp. 323-4). At the same time, however, they claim that:

\begin{abstract}
"In a static and mechanistic style of economic theory, such natural monopoly would demand government intervention, perhaps even nationalization of the railroads, in order to prevent a loss in public utility owing to monopoly pricing - a view, in fact, that Walras... advanced. However, in Dupuit's opinion this kind of market failure did not demand either of these 'solutions'. Owing to locational forms of competition and the benefits of an open competitive process, wherein high profits were conductive to entry, Dupuit thought that competition in railway transportation would be no more injurious or wasteful than between butchers and bakers" (Ibid.).
\end{abstract}

They thus believe that, unlike Dupuit, Walras did not understand the dynamic nature of competition: monopoly is temporary. The inefficiency of the French railway system derived from government intervention: while Dupuit "conceded that the French transport market was inefficient, ... [he] attributed the cause to government intervention, not to natural monopoly" (2003, p. 670). As a result, the State should not operate in the railroad sector because unlimited competition is feasible (2012, p. 104).

In contrast to Ekelund and Hébert, Béraud (2005a), Manuela Mosca (2008) and Numa (2012) maintain that Dupuit advocated State intervention in the railroad industry. Their interpretation is based on Dupuit's assertion that the railroad industry is a natural monopoly: high fixed costs imply increasing returns to scale and, hence, a monopoly. For instance, Mosca states that Dupuit "identified the transport network as a situation in which a natural monopoly 
would have occurred, and claims that he made a first step in the elaboration of the decreasing average cost function" (2008, pp. 339-43). ${ }^{4}$ In the same line, Numa concludes that Dupuit "recommended State intervention in the railroad industry, showing that a public monopoly is preferable to a private one" $(2012$, p. 86$)$, adding that the engineer "believed competition was the general functioning principle of economic activity. Nevertheless he [Dupuit] also believed that, in few industries such as the railroad industry, the facts demonstrated that competition was impossible and wasted resources" (Ibid., p. 81).

According to these interpretations, Dupuit's positions on the railroads would thus be inconsistent: on the one hand, unlimited competition is the most efficient way to operate in the railroads; on the other hand, State management is the best way to run the railway system.

The aim of this article is to show that Dupuit's thought on the issue of railroads is not inconsistent. The consistency of his position becomes clearer as soon as one distinguishes between two issues: unlimited competition in the rail transport industry, and the extent of State intervention in the railroads. I will deal with these two issues successively. While Dupuit considered unlimited competition as an ideal both for society and in the railroads sector, in Section II I argue that he believed that unlimited competition in the railroads is not necessarily good for the welfare of society and that it was not possible in his own era. That is why he maintained that State management of the railroads is superior to private monopoly in the event that there is no intermodal competition and no intramodal competition. ${ }^{5}$ This is what I will try to establish in Section III.

\footnotetext{
${ }^{4}$ See also Béraud (2005a, p. 15 and p. 20) and Numa (2012, p. 77).

${ }^{5}$ Dupuit never used the expressions "intermodal competition" and "intramodal competition"; however, he developed types of competition which are today called by these names (see infra, section III).
} 


\section{DUPUIT'S POSITION ON UNLIMITED COMPETITION IN THE RAILROAD SECTOR}

Dupuit tackled the issue of the management of railroads on several occasions: in his entries "Péages" (1853b) and "Voies de communication" (1853a) in the Dictionnaire de l'Économie Politique (DEP); in two debates at the Société d'Économie Politique (SEP) (1853c, 1862a); in the Dictionnaire général de la politique (1863a) and Dictionnaire universel théorique et pratique du commerce et de la navigation (1861a); and finally, in a letter written in response to Adolphe Blaise's criticisms of Dupuit's position on the fares applied by concessionaires (1862b).

Throughout these works, Dupuit adopted a two-step reasoning process. He first considered unlimited competition as an ideal for society as well as for the operation of the railroad sector (II.1). Then he discussed the possibility of unlimited competition in practice. In particular, he distinguished between two questions. First, is unlimited competition good for the welfare of society in the railroad industry (II.2)? Second, can this kind of competition emerge in the railroads from a monopolistic situation (II.3)?

\section{II.1. Unlimited competition: an ideal for society and for the railroad sector}

In line with the engineers of Polytechnique and the Ecole des Ponts et Chaussées (François Etner 1987; Bernard Grall 2004, p. 31; Mosca 1998; Cecil O. Smith 1990), Dupuit always referred to public interest: for him, this consists in achieving the goals of society. More precisely, it aims at maximizing the welfare of society under two constraints:

- restricting as little as possible natural liberty, that is, the degree of liberty of individuals in the natural state $(1861 \mathrm{~b}$, p. 636); 
- protecting other natural rights $^{6}$.

According to Dupuit, the welfare of society is a part of the public interest and corresponds to the satisfaction of individuals' needs (Philippe Poinsot 2011). It thus depends on the quantity of wealth and population (Poinsot 2010, 2011).

In order to achieve this goal, the legislator should base his decisions on an impartial criterion: Dupuit called this "public utility", which is a quantitative notion that political economy indicates to the legislator in order to increase wealth and so the welfare of the nation (Ibid.). While "public utility" is the only public decision-making principle, it lends itself to a variety of solutions according to time and space (1861b, p. 633). In particular, the solution depends on the characteristics of the goods, and on the technological, social and economic conditions of society and of the period. ${ }^{7}$

Because of the nature of public interest, the optimal solution would be to maximize the welfare of the nation by ensuring the same degree of individual liberty as in the natural state. In practice, this leads Dupuit to adjudicate in favor of unlimited competition, which only takes place in what he referred to as "normal industries" (1862a, p. 587) which have three characteristics: i) they are open to any producer; ii) wages depend on the quantity and quality of labor, and iii) the price of goods is determined by the law of supply and demand (Ibid., p. 584). The price which results from unlimited competition, which Dupuit referred to as the "natural price" 8 (1853a, p. 447), is considered as a norm for all sectors of the economy. For instance,

\footnotetext{
${ }^{6}$ The other natural rights which may be protected entirely by the legislator are self-ownership, self-defense and the respect of free contracts and conventions. For a more detailed examination of Dupuit's conception of public interest, see Poinsot $(2010,2011)$.

${ }^{7}$ See section III. For more details on the criterion of "public utility", see Poinsot (2011, pp. 356-74).

${ }^{8}$ Dupuit's conception of natural price is thus different from that of Smith and Ricardo as natural price is derived from unlimited competition.
} 
for the means of transport, he claimed that the "natural toll" is that which would result from the freedom to produce and to consume... and would leave the venal price close to the cost of transport" (1853b, p. 529). It follows that the best way to manage the railroad industry is the system which offers the price closest to the natural price. Indeed, in his response to Adolphe Blaise's criticisms, Dupuit states:

\footnotetext{
"What I wish is that railroad customers pay only the cost of transport, whether passenger or merchandise, just as they would on former means of transport if unlimited competition existed. I am very much disposed to adopt any solution that leads to this result" (1862b, p. 597).
}

Knowing that unlimited competition is regarded by Dupuit as an ideal for society and for the railroads, does this mean that it is necessarily good for the welfare of society in practice? This is the question that will be answered in the next section.

II.2. Is unlimited competition in the railroad industry necessarily good for the welfare of society?

Dupuit distinguished between two questions: unlimited competition on a railway line (which today is called vertical unbundling) on the one hand, and unlimited competition between parallel railway tracks on the other hand.

Concerning vertical unbundling, one can distinguish between full vertical separation and partial vertical separation. The former is institutional separation between infrastructure ownership and rail operators (Didier van de Velde \& al., 2012, p. 26). Partial vertical separation corresponds to a situation where a vertical integrated railway company which both owns and operates a rail track provides access to competing railway companies through the payment of tolls. Although the former did not appear in the debates in France, the latter - the pos-

\footnotetext{
${ }^{9}$ As I point out in section II.2, Dupuit rejected vertical separation for the railroads, which led him to consider "toll", "fare" and "price" to be synonymous.
} 
sibility for a railway company to use the infrastructure of a vertical integrated railway company - was at least provided for in the concession agreement of the Paris-Saint-Germain-enLaye in 1835 (Numa, 2009b, pp. 168-70; Ribeill, 1997, p. 32). However, partial vertical separation was not translated into reality during the nineteenth century (Numa, 2009b, pp. 16870). Dupuit, like many engineers of his time (Numa 2011, p. 4), considered vertical unbundling (full and partial) in the railroads to be harmful for society. Indeed, unlimited competition in a railway line creates safety problems: "on the railroads, the safety of operation requires that all the transportation expenses be bundled together and concentrated under the supervision of a single person" (1853a, p. 443). Ten years later in "Chemins de fer", Dupuit distinguished railroads from roads and ship canals:

\footnotetext{
"On roads, on ship canals, competition is unlimited: everybody can use his (her) car or his (her) boat by paying a small fee. For reasons of safety, the same would not apply for railroads. At the beginning of railroads, it was hoped that there would be possible to have trains of various railway companies on the same line; but, after many accidents, it has been acknowledged that it is difficult for each company to have the same railway operating rules..."(1863a, p. 480; see also 1861a, p. 471).
}

For Dupuit, roads, ship canals and railroads are distinguished by the fact that the latter uses a technology which requires a high degree of coordination between the relevant companies. His argument is very similar to that used today for supporting vertical integration (Didier van de Velde et al. 2012, p. 14): he refers to an increase in the complexity of interfaces and so in the cost of coordination between railway companies resulting from vertical separation (Dupuit 1863a, pp. 479-80). However, Dupuit never discussed an argument which is framed today in favor of full and partial vertical separation and which could offset the increasing cost of coordination: an increase of competition between railway companies may lead to the provision of better services and to a reduction of costs (Didier van de Velde \& al., 2012, p. 14). 
Thus, for Dupuit, although vertical separation (full and partial) is technically possible, a given railway service with vertical unbundling is more economically costly than vertical integration. This is why he claimed that "their operations [of railroads] exclude [unlimited] competition which can only take place between different railway tracks or others means of transportation" (1861a, p. 471). Although he did not say so, it results from this rejection of vertical unbundling that he does not distinguish between the building/ownership of the railway network and the operation of the network, something which led him to treat the owner of track and the rail operator as synonymous. ${ }^{10}$ Thus, unlike economists today, he assumed that there is no distinction between the toll paid to the owner of the rail infrastructure and the user fare for the rail service. ${ }^{11}$ For Dupuit, the user fare ${ }^{12}$ should cover both the cost of building and maintaining the tracks and the network, and the cost of running the train on the tracks (see section III.1.1). Dupuit's imprecision may explain why the historians of economic thought have developed different interpretations on his position on the issue of railroads.

Dupuit's discussion of the virtue of unlimited competition between parallel railway tracks can be found in "Péages" (1853b) and "Voies de communication (I)" (1853a) in the $D E P$, and in a debate at the $S E P$ concerning monopoly in the railroad industry (1853c). And, curiously, he assumes two opposite positions: on the one hand, in "Péages" and "Du monopole des chemins de fer", he denounces the negative consequences of unlimited competition for society. On the other hand, in "Voies de communication (I)" (1853a), he presents unlimited competition as the most efficient means of managing the railroads and increasing the welfare of society. One might argue that he changed his position; but this argument cannot be sustained, since all these articles were written in 1853.

\footnotetext{
${ }^{10}$ This implication was suggested to me by one of the referees, to whom I offer sincere thanks.

${ }^{11}$ Echoing Dupuit, when speaking of railroads I will consider "toll", "fare" and "price" to be synonymous.

${ }^{12}$ In accordance with his conception of ethical justice, Dupuit claimed that the means of transportation must be financed by users. Dupuit only recommends taxing all members of society (users and non-users) for roads because this cannot be achieved fairly and economically. For more details, see Poinsot (2010, 2011, pp. 141-6).
} 
On the one hand, in "Péages", Dupuit claims that unlimited competition is harmful to the wealth of society, adopting the following rationale: he imagines an initial firm with monopoly power which yields extra profit. A new firm wishes to enter the market. According to him, if this were to occur, it would diminish the revenue of the entering firm and diminish the revenue of the incumbent. Dupuit concludes: "the new company would have significantly harmed the incumbent one...; instead of one good deal, there would be two bad ones" (1853b, p. 520). But on the other hand, in "Voies de communication (I)" (1853a), he claims that unlimited competition in the railroad industry increases the welfare of the nation: "with regard to the building of railway tracks and means of transport, complete competition and freedom is the true economic solution" (1853a, p. 450). Unlike his contemporaries, ${ }^{13}$ Dupuit affirmed that unlimited competition in the railroad industry would not create a greater waste of resources for the nation than in any other industry. In reference to the example of the two companies operating a service between Paris and Versailles (one via the left bank and the other via the right bank), he claims:

"A rival company builds a second, manifestly parallel [line]. As a result, the nation loses a capital nearly equivalent to the value of the latter's track. The two railroads from Paris to Versailles exemplify the consequences of unlimited competition in railroad construction. It must be acknowledged that this causes a serious disadvantage; but, to our way of thinking, it is much less than what happens under monopoly, and perhaps even less than the consequences of State operation. It is largely unnoticed that this disadvantage, which made such a powerful impression when these lines were being constructed, is present in all kinds of industry. It is quite evident that the parceling out [of business] among a large number of vendors raises enormously the capital necessary for production to take place, which is more than occasionally lost, causing costs to multiply. Walking the streets of a major city, for example, we are struck by the proximity of one tailor next to another, one cabinet maker beside another... To what advantage? One of the two is evidently sufficient to satisfy the public need..." (Ibid., pp. 451-2).

\footnotetext{
13 The engineers of Ponts et Chausées and of the Mines worried about the profitability of these railway tracks. See Yves Breton \& Gérard Klotz (2009, p. 451, footnote no. 54).
} 
He concludes that "unlimited competition, regarding the means of transport, would not cause more disadvantages than it would elsewhere" (Ibid.).

Dupuit's position on the virtue of unlimited competition between parallel railway tracks for society is thus ambiguous. We will see that his change of mind is simply due to the fact that he considered that unlimited competition was impossible in the railroad sector in France in his period.

\section{II.3. The characteristics of railroads prevent unlimited competition}

Dupuit stated that railroads are monopolies (1863a, p. 480) and that State intervention is necessary in order to limit the harmful consequences of monopoly, but "when railway operations are subjected to the law of competition, there will be no reason for State intervention..." (1862a, p. 587). He adds:

"It would be a happy occurrence if we were to find a means of eliminating some of the disadvantages facing companies which result from a monopolistic situation and to find a way of stimulating competition" (Ibid.).

In order to clarify his position, Dupuit differentiated three kinds of industry in society: a) normal industries, b) collective industries, and c) industries which are "necessarily monopolies" (Ibid., pp. 584-5). They are distinguished by three characteristics: i) the capital to produce goods, ii) the way workers' wages are set, and iii) the degree of competition in the market.

As mentioned above (see p. 6), in normal industry there are no barriers to entry, workers are paid according to their work, and the price of goods is determined by the law of supply and demand. As a result, in these industries, government intervention is not required: 


\begin{abstract}
"The State can only produce with workers whose salary... is proportional neither to the quality, nor the quantity of products. As these workers are not stimulated by personal interest, which is the most powerful rationale in ordinary acts of life, they would produce much less than free workers [whose] wage [depends] on merit and the quantity of individual work" (Ibid.).
\end{abstract}

Conversely, collective industries (i.e. ironworks, credit industry) need huge amounts of capital (1862a, p. 584) and workers are in the same position as civil servants because "their wages are fixed and independent of their work" (Ibid.). ${ }^{14}$ Consequently, it is impossible "to invoke against State management of collective industries the argument of personal interest" (Ibid.). However, as private companies are in competition with each other, the State is less efficient than private firms. Dupuit used three arguments to justify this position. First, unlike in the case of public management, competition stimulates firms "to satisfy users' tastes" (Ibid.). Second, in contrast to civil servants, workers in collective industries can be laid off due to firm bankruptcy: indeed, a "forge, a mine, a badly managed bank soon go bankrupt and so all their workers lose their wages" (Ibid.). Third, firms in collective industries are price takers: "the price of their services is set by the law of supply and demand, and the consumer cannot complain" (Ibid). Then, "if the State were to operate a forge or bank, it would experience no rivalry; as a result, its production would be worse than these big companies" (1862a, p. 584). That is why government intervention is not necessary in collective industries.

Dupuit identified a third type of industry requiring huge capital and in which workers' wages are set independently of their work. Unlike collective industries, firms in these industries can set a monopoly price:

"the situation is different for some industries, i.e. railroads, because they are inevitably monopolies. On the one hand, their workers... are not concerned by the result of their works as they are in the collective

\footnotetext{
${ }^{14}$ Dupuit made the same point in his review of Molinari's Question d'économie politique et de droit public. See Dupuit (1863b, pp. 128-9).
} 
industries; and, on the other hand, they are not worried... by users' needs because consumers cannot use other means of transports" (Ibid., pp. 584-5).

Dupuit named these industries "natural monopolies" (Ibid., p. 587) ${ }^{15}$ in contrast to "artificial monopolies" (Ibid.). While artificial monopolies (Banque de France, Crédit Foncier, Crédit Agricole...) arise by law, natural monopolies derive from the "nature of things". As a result, the "drawbacks of artificial monopolies are easy to break, as it is simply a question of eliminating the monopolies themselves. This solution cannot be applied to natural monopolies" (Ibid., p. 589).

For Dupuit, the rail industry is emblematic of the natural monopoly. Two points need to be made to clarify his position: the first deals with the reasons why he considers that railroads are a natural monopoly; the second looks at the distinction between infrastructure and operation in relation to this issue of natural monopoly.

This industry's character as a natural monopoly arises from the existence of barriers to entry. Indeed, in a previous debate at SEP (1853c) and in his article "Péages" in the DEP (1853b), he mentions two kinds of barrier to entry in the railroads: the high level of fixed costs in absolute value, and the inherent advantages of the incumbent.

First, Dupuit considered fixed costs in two ways: in relative value and in absolute value. ${ }^{16}$ While, in the railroads as well as any kind of industry, fixed costs correspond to $3 / 4$ of annual expenses (Ibid., pp. 528-9), they are, in absolute value, much higher in the railroads than in any other industry. This entails barriers to entry because "once a firm is established with a capital of 40, 50 or 100 million, etc., no rival companies... can be set up, because this sum of

\footnotetext{
${ }^{15}$ According to Dupuit, natural monopolies include the railroads, gas distribution, water distribution, the telegraph, etc. See Dupuit (Ibid, pp. 588-9).

${ }^{16}$ This distinction has not been made by Béraud (2005a), Mosca (2008) and Numa (2012). However, it is important as it is the only way to understand the two subsequent statements by Dupuit: on the one hand, fixed costs stand in the same proportion in every industry and, on the other hand, fixed costs are higher in the railroad sector than in every other industry.
} 
money is always difficult to collect..." (1853c, p. 574). The capacity to build new infrastructure is thus limited to a small number of people (1853b, p. 520).

Second, Dupuit adds that even where firms have enough capital to build parallel railroads, "as the incumbent company is the only one in the market, the new one cannot compete with the first one, and the profit made by one is not enough for two" (1853b, p. 520). ${ }^{17}$. As stated by Mosca (2008) and Numa (2012), the first firm always has advantages on the choice of the road, clientele habits, and so on:

\footnotetext{
"it is highly probable that the first company, which, as the first company, was the first to choose a route, chose the best one... therefore the next company's route will be necessarily inferior in terms of land quality, wealth, population.... Then it arrives after the customers of the railroad have formed habits and established relationships with it; it can only hope to take half of the clientele of the incumbent company [which insure law benefits to the entering firm]...". ${ }^{18}$
}

As regards the elements which are subject to natural monopoly, these can pertain to:

i. The infrastructure

ii. The infrastructure and operation

For roads and ship canals, Dupuit was explicit: it is only the infrastructure which is subject to natural monopoly (1861a, p. 471; 1863a, p. 480). For railroads, he was more ambiguous, which again may explain that historians of economic thought have developed different interpretations on his analysis of railroads. He sometimes refers only to infrastructure to justify the characteristic natural monopoly of railroads (1853c, p. 574), while sometimes he argues that it is both the infrastructure and operation which are subject to natural monopoly. For instance, in "Péages", he states that the "means of transportation [as railroads], whose construction and operation require substantial expenses, are monopolies..." (1853b, p. 520). Furthermore,

\footnotetext{
${ }^{17}$ The same argument was used by Dupuit for another natural monopoly: the water supply network. See (1852, p. 540).

${ }^{18}$ (1853b, p. 520). See also Dupuit (1853c, p. 574).
} 
when he discusses this issue, it seems that Dupuit is confusing two different questions: the possibility of vertical separation, and which elements are subject to natural monopoly.

One explanation for Dupuit's lack of clarity is that his discussion of natural monopoly refers to the possibility of unlimited competition in the railroads. From this point of view, whatever elements are subject to natural monopoly (infrastructure, or infrastructure and operation), as soon as he rejects vertical separation, both cases lead to the same result: unlimited competition is not possible in the railroads. Indeed, if the rail infrastructure and operation are natural monopolies, it is easy to understand why unlimited competition is not possible. ${ }^{19}$ Imagine now that infrastructure is the only element that is subject to natural monopoly. It follows from Dupuit's rejection of vertical separation - which means that there is a relationship between the ownership of infrastructure and railway operation - that a natural monopoly on building and ownership implies a monopoly on railway operation. Thus, in both cases unlimited competition is impossible.

For Dupuit, the railroad industry is thus a "de facto monopoly" (Ibid., p. 519) and a "monopoly can draw a revenue from it that is superior to that of capitals submitted to competition" (Ibid., p. 520). Nevertheless, this situation may change in the future with the evolution of technology: some sectors of the economy in which unlimited competition was possible in the past became natural monopolies through the technological revolution. For instance:

"When public lighting was oil lighting, competition was unlimited; with gas, which required burying the gas pipe, public lighting became a monopoly. The evolution of some industries change their own nature and we have to accept the consequences in terms of management" (1862a, p. 588).

Dupuit assumed that the opposite could be true for railroads: that is why, in the future, unlimited competition could be possible in the railroad sector. In his own period, however, the bar-

\footnotetext{
${ }^{19}$ It should be mentioned that this does not imply that State must build and operate the rail track. See section III, below.
} 
riers to entry prevented such competition, and the company which exploits the existing track does indeed benefit from a de facto monopoly. This company will set a price that maximizes its profits. Thus, intervention by the State is justified, and its form has to be determined. But should the State grant the track to a private company via concessions, or exploit it directly? This is the object of next section.

\section{STATE MANAGEMENT VS. PRIVATE MONOPOLY (OR CONCES- SIONS)}

When Dupuit addresses the issue of the best way to manage the railroads, he seems to draw a comparison between concessions and State management. This is not surprising if we consider the period in which he was writing. Between 1823 and 1832, railroad concessions could not transport passengers but only build and operate goods-transport networks, in particular for coal. While government intervention was kept to a minimum with regard to financial assistance and the operation of railway lines, the State granted perpetual concessions. In 1833, the government began to control the concessionaires for the development of passenger transport: on April 26, 1833, the concession length was reduced to 99 years and a maximum legal fare was created to control the fare applied by concessionaires. ${ }^{20}$

However, Dupuit's arguments could be applied to concessionaires with the maximum legal fare as well as non-concessionaire private companies. For instance, as I will show in the next section (see section III.1.1), the main disadvantage of a monopoly is the toll rate applied by a private firm seeking to maximize its revenues. Then, the only difference between the concessionaire and the private company is that, even though a higher toll rate increases its revenue, the former only equates its price to the maximum legal fare. That is why I use the term "company" to speak of concessionaires as well as non-concessionaire private companies.

\footnotetext{
${ }^{20}$ For more detailed information on the development of the railroads in France, see François Caron (1997) and Numa (2009a, pp. 107-12; 2012, pp. 73-6).
} 
As stated above (section II.1), Dupuit believed that the decision on whether to support government intervention in the economy should be based on "public utility". State management is required when it can increase the quantity of wealth for society more than any other kind of management. In accordance with "public utility", Dupuit offered various answers to the issue of how best to run the railroads. ${ }^{21}$ In particular, he distinguished between railway lines in which there is no intermodal competition (the individual has no choice between different means of transportation (i.e. roads and ship canals) for the same Origin-Destination $(\mathrm{O} / \mathrm{D}))$ and no intramodal competition (the individual has no choice between different railway lines for the same O/D) on the one hand (III.1), and railway tracks in which there is intermodal competition and/or intramodal competition on the other (III.2).

III.1. A State-operated system is superior to private monopoly in the event of no intermodal competition and no intramodal competition

To identify the cases in which there is no intermodal and no intramodal competition, Dupuit discussed the criteria for the choice of the mode of transportation and the availability of alternative options in terms of travel.

Although the choice of the mode of transport for him depends on two criteria - speed and transport cost -, according to the nature of the commodity to be transported (passenger, perishable freight and non-perishable merchandise), one criteria will be more important than the other. $^{22}$

When speed is the most important criteria for the choice of the mode of transportation, such as for passengers (1863a, p. 480) as well as for perishable freight, the railroads enjoy a huge

\footnotetext{
${ }^{21}$ Traditionally, the secondary literature claims that the "pragmatic" approach of Dupuit was in complete contrast to the ethical and ideological approach of Léon Walras, since the latter justified State intervention in the railroad industry according to the notion of service public. For more information, see Béraud (2005a), Ekelund \& Hébert (2003) and Numa (2012).

${ }^{22}$ It should be mentioned that Clément Colson in Transports \& Tarifs (1908, pp. 633) also claimed that speed is the most important criteria for passengers, while for freight it is transport cost.
} 
advantage over roads and ship canals (1861a, p. 472). ${ }^{23}$ Then, there is no intermodal competition and no intramodal competition, whatever the availability of alternative options in terms of travel may be. Dupuit's affirmation is questionable: in fact, the validity of his argument depends upon certain hypotheses regarding the value of time for individuals. For instance, if alternative means of transport are available, his argument is only consistent if he assumes that the value of time of individuals is very high. Otherwise, there is either intermodal or intramodal competition. More generally, the more highly the individual values time, the lower the intermodal or intramodal competition will be.

Unlike passengers and perishable freight, transport cost is the most important factor in the choice of mode of transport for non-perishable merchandise: the advantage of railroads in terms of speed is no longer relevant. In that case, the existence of intermodal competition and/or intramodal competition only depends on the availability of alternative options in terms of travel: the absence of any alternative options implies no intermodal competition and no intramodal competition. This is what Dupuit meant when he claimed that if "I wish to transport merchandise from Paris to Lille, I have to pay the railway company toll, because there is no other choice" (1853b, p. 519).

Thus, there is no intermodal competition and no intramodal competition either if speed is the most important criteria for the choice of the mode of transportation, or there is no alternative option available. For both cases, Dupuit's comparison between operation by the State and by a company is based on two dimensions: fares applied to users (III.1.1) and the effi-

\footnotetext{
${ }^{23}$ Due to the Restauration (1815-1830) and the Monarchie de Juillet (1830-1848), the road network and the waterways network were well developed in France in the nineteenth century (Caron, 1997, pp. 50-4; Pierre Léon, 1976; Emile Levasseur, 1912). However, it should be noted that, for freight transport, the historians of economics (Caron, 1997, pp. 352-8; Numa, 2009b, p. 211), as well as Alfred Picard (1887), most often mentioned ship canals as a significant competitor for railroads. For the transport of passengers and freight, the road network only seemed relevant to connect the points which were not served by railroads (for instance see Caron, 1997, pp. 34552). This might seem surprising, and will be clarified in a future article.
} 
ciency of the organization structure (III.1.2). I will now go to Dupuit's arguments in favor of the State-operated system with regard to fares applied to users.

\section{III.1.1. Uniform price versus price discrimination}

When price discrimination is not applied by the railway's owner, the State seeks to maximize the "public utility" of the infrastructure, whereas a private company wants to maximize its own revenue:

"In price setting, two points of view are possible. In the case of a private company, it would obviously seek to obtain the highest revenue... If it is the State that exploits the industry, as it is likely that it will want to cover the interest of capital borrowed and the maintenance costs, it would charge a much lower rate than the company. The lower the toll, the more users there are and the more the means of transportation is useful" (Dupuit 1853b, p. 524; see also 1853c, p. 575).

A government wants "a fixed sum representing interest on the capital spent for construction, maintenance cost and perhaps amortization" (1849 [1962], p. 11). ${ }^{24}$ As the demand function is given by $Q=f(p)(1844 \text { [1952], p. 107 })^{25}$ with $Q$ the quantity transported and $p$ the toll, then, according to Dupuit, the State's equation is (Ibid.):

[1]

$$
M=p f(p)
$$

with $M$ representing construction costs and the interest on the capital borrowed.

\footnotetext{
${ }^{24}$ In this quotation, Dupuit speaks of all means of transportation. As mentioned before (section II.2), he rejected vertical separation for railroads, which led him to treat the ownership and the operation of the network as synonyms. Thus, user fares should cover both the cost of building and the maintenance costs of the railway track, as well as the cost of running the train on the tracks.

${ }^{25}$ For more information on the construction of the demand function in Dupuit's thought, see Béraud (2005b), Norman E. Daniel (1971), Arnaud Diemer (2003), Ekelund (2008), Ekelund \& William P. Gramm (1970), Ekelund \& Hébert (1999) and (2002), R. W. Houghton (1958), Poinsot (2011, pp. 361-70), Ralph W Pfouts (1953, p. 316), Jean-Marc Siroën (1995, pp. 36-41) and Stigler (1950, pp. 313-4).
} 
Whereas the State puts a price to cover the construction costs and the interest on the capital borrowed, a private company wishes to maximize its revenues, which means that it will solve the following equation (1844 [1952], p. 108):

$$
\frac{\partial p f(p)}{\partial p}=0
$$

Suppose (Graph $1^{26}$ ) that $p_{E}$ is the solution to [1] whereas $p_{C}$ solves [2]. $M$ equals B $+\mathrm{D}$ and the revenue of the private company is the area D $+\mathrm{E}$. The "utilite relative" (relative utility hereafter) of consumers - which is the difference between users' reserve prices (what Dupuit refers to as the "utilité absolue" - what I will call absolute utility - of the individuals ${ }^{27}$ ) and the price - is higher in the case of public management (area $\mathrm{C}+\mathrm{E}+\mathrm{F}$ ) than private monopoly (F). Consequently, deadweight loss is lower for public management (area A) than the private firm $(\mathrm{A}+\mathrm{B}+\mathrm{C})$, and, in comparison to a private monopoly, public management increases the absolute utility (or the "public utility") of the infrastructure - the sum of the owner's revenue and the relative utility of consumers - by $\mathrm{B}+\mathrm{C}$.

\footnotetext{
${ }^{26}$ Echoing Dupuit, I put $Q$ on the $y$-axis and the fare $(p)$ on the $\mathrm{x}$-axis.

${ }^{27}$ The traditional reading of Dupuit interprets his concepts of absolute utility and relative utility in a Marshallian way. In other words, these concepts are generally considered as being synonymous with, respectively, the individual welfare (or utility function) and the consumer's surplus. See Ekelund \& Gramm (1970), Ekelund \& Hébert (1999), Houghton (1958), Mosca (1998), Pfouts (1953). For alternatives interpretations, see Maurice Allais (1989, pp. 164-5), Béraud (2005b), Poinsot (2011, pp. 205-22).
} 


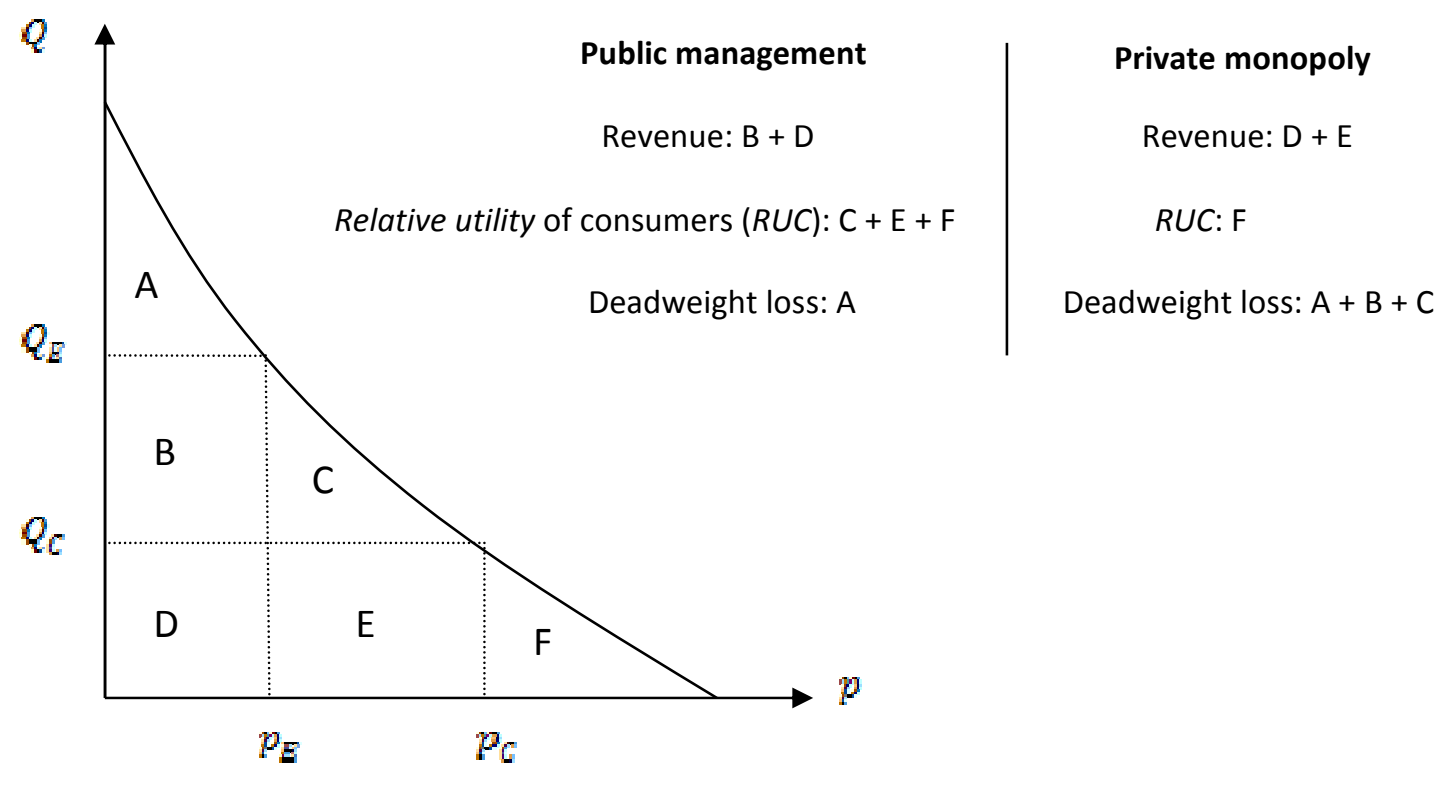

Graph 1: Variation of deadweight loss between public management and private monopoly

With uniform price, a natural monopoly should be managed by State.

Now let's see what happens, for Dupuit, with price discrimination. According to him, a uniform price is indeed not the optimal system of taxation. In order to compare different modes of taxation, two dimensions are considered:

i. Does the type of taxation enable construction costs and capital interest (and operation costs for railroads) to be paid?

ii. What is the best mode of taxation to maximize "public utility"? In other words, what is the fare system which enables all individuals to use the infrastructure?

The second point may seem surprising to modern economists: but it derives from the importance that Dupuit assigns to the "public utility". Indeed, what was important to him was not the relative utility of consumers but the "public utility" of infrastructure: a method of taxation which does not prevent any individual from using the infrastructure is better than any other method of taxation, whatever the relative utility of consumers are.

While he considered that a uniform price which repays construction costs and capital interest (and operation costs for railroads) is equivalent to price discrimination in terms of dimension 
(i), Dupuit was in favor of the latter because "public utility" is higher with price discrimination than with a uniform price (dimension (ii)) (1853b, pp. 528-9).

According to Dupuit, the optimal system of taxation was perfect price discrimination in order to maximize "public utility": the "skill of the operator is thus to set the maximum price for any passenger and any merchandise that would lead them to use the railway track" (Dupuit 1863a, p. 481). While perfect price discrimination is not possible in practice, Dupuit argued that this is the kind of taxation which should be sought by the owner of a road. ${ }^{28}$ Indeed, he claimed that the latter should differentiate between consumer categories, set various prices according to the users' elasticity of demand (Ekelund \& Hébert 1999, p. 195; Mosca 1998), ${ }^{29}$ and use spatial discrimination (Diemer 2000; Ekelund \& Hébert 1999, pp. 259-61; Ekelund 1970; Ekelund \& Yeung-Nan Shieh 1986). Suppose (Graph 2, p. 23), for instance, that the railway owner distinguishes between three categories of user: first-class users have to pay price $p_{1}$ to use the infrastructure, whereas second-class and third-class users pay $p_{2}$ and $p_{3}$ respectively. There are $Q_{1}, Q_{2}$ and $Q_{3}$ users in first, second and third class. Compared to uniform price ( $p_{E}$ in Graph 2), the revenue of the railway's owner increases by B $+\mathrm{I}$ and the deadweight loss decreases by B + C. Consequently, the "public utility" of the infrastructure increases with regard to uniform price. ${ }^{30}$

\footnotetext{
${ }^{28}$ The railway companies in France during the nineteenth century practiced strong price discrimination. For more details, see Caron (1997, pp. 386-9) and Numa (2009b, pp. 117-9).

${ }^{29}$ Dupuit advised the operator to charge higher tolls on captive consumers.

${ }^{30}$ The result is ambiguous for the relative utility of consumers. In our example, price discrimination will only decrease the relative utility of consumers if $l$ is larger than $C$.
} 


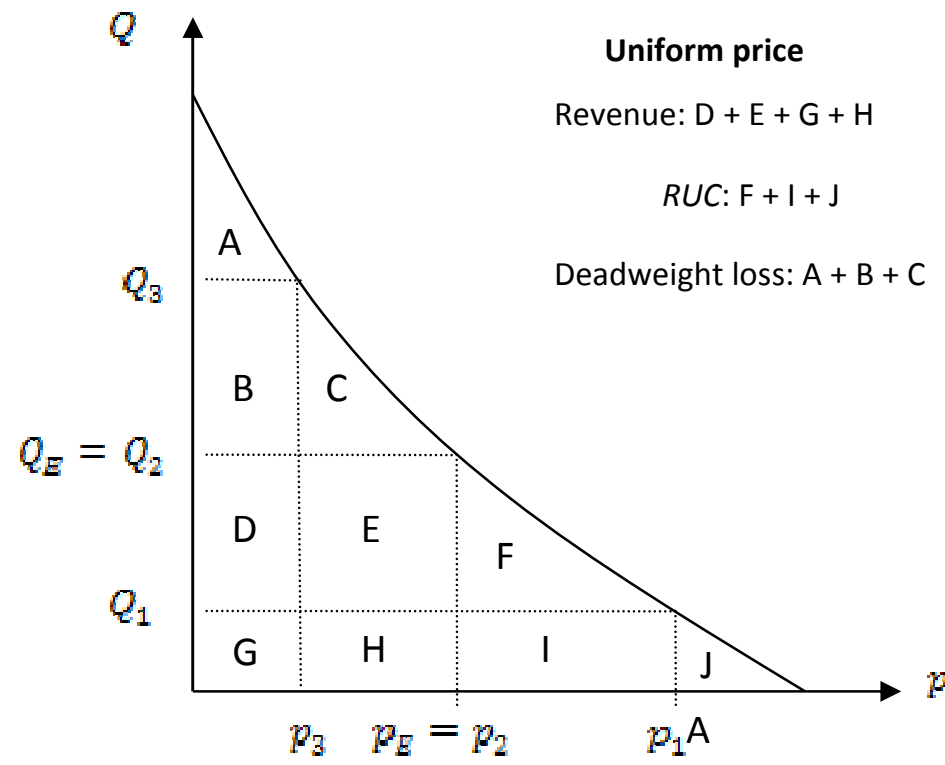

Third class price discrimination

Revenue: $\mathrm{B}+\mathrm{D}+\mathrm{E}+\mathrm{G}+\mathrm{H}+\mathrm{I}$

$R U C: \mathrm{C}+\mathrm{F}+\mathrm{J}$

Deadweight loss: A

Graph 2 : Comparison of deadweight loss between uniform price $\left(\mathbb{P}_{\mathbb{Z}}\right)$ and third class price discrimination

$\left(p_{1}, p_{1}, p_{2}\right.$ for the consumers of the first, second and third class)

As price discrimination increases the owner's revenue, the private company, as well as the government, should prefer it to uniform price. This suggests that, for Dupuit, State management is equivalent to private monopoly with regard to "public utility" in the situation of price discrimination. Nevertheless, he seemed to prefer government management, arguing that civil servants are more efficient than "private servants" in the case of no intermodal competition and no intramodal competition.

\section{III.1.2. Civil servants are more efficient than "private servants"}

According to Dupuit, the State is more organized ${ }^{31}$ than a private company because civil servants are more efficient than workers in a private monopoly, who can also be referred to as "private servants". For instance, he claimed that:

“economists' arguments to refuse State management of the majority of industries cannot be applied to the railroad industry. When a producer... earns a wage corresponding to his product quality and quantity, he provides good work and produces as much as possible, whereas he works... as little as possible

\footnotetext{
${ }^{31} \mathrm{He}$ considered that the only advantage of a private company over State ownership relates to the choice of route, because political considerations have no impact on companies' choice (1863a, p. 482).
} 
when, as a civil servant, he earns a fixed salary...In the railroad industry, all workers earn fixed wages and they are not interested in the welfare of the company any more than civil servants are of the welfare of the State" (1863a, p. 482).

And he added that "the workers of a company... are a kind of civil servant; from the lengthman who straightens the tracks to the director who manages the operations, the only incentive to stimulate their natural laziness is their conscience" (1853, p. 448). Dupuit invoked two arguments to support his position: i) the State's organization against the laziness of civil servants, and ii) civil servants' desire to serve the society:

"Society has taken special and numerous precautions against the indifference, laziness and lack of integrity of civil servants. Although less powerful than personal interest, considerations resulting from the honor of serving the State are motives which have an impact which cannot be overlooked" (Ibid., p. 449).

Moreover, unlike the workers of a private company, the work of civil servants is better controlled by the press and citizens: "public opinion and the press have some control over civil servants which does not exist for the workers of companies because the latter are seen as private producers criticism of whom would seem to be slanderous" (1863a, p. 482; see also 1862a, p. 586).

Thus, government management of a natural monopoly is more efficient with regard to "public utility" than a private monopoly for railway lines when there is no intermodal competition and no intramodal competition. The situation is different when there is competition from roads, ship canals or other railway lines. 


\section{III.2. Private monopoly is superior to State management in case of intermodal}

competition and/or intramodal competition

In his letter reproduced in the Journal des Économistes, Adolphe Blaise (1862) criticized Dupuit, arguing that railroad concessionary companies do not set prices equal to the maximum legal fare. In fact, for Dupuit, this is only true for railway tracks transporting nonperishable goods because in that case there is intermodal competition and/or intramodal competition. In the case of non-perishable freight, the choice of transportation is determined by the costs of transportation: as speed is no longer relevant, a railway track loses its advantage over roads, canals and other railway lines. Intermodal competition and/or intramodal competition puts pressure on the railway line's owner to keep their prices down: "If railway companies set their prices, in certain circumstances, below the legal price for merchandise, this is solely the result of competition from other means of transport" (1862b, p. 595). In other words, there is no point in the railway track owner setting a high price because freight transport is intermodal (Ekelund \& Hébert 2003, p. 670): high tolls lead merchants to use either other means of transport or other railway tracks. However, Dupuit criticizes Blaise's assertion that this would show that company interests coincide with consumer interests: the railway line's owner always sets his price to maximize his revenues.

Thus, the owner of a railway track in which there is intermodal competition and/or intramodal competition will set his prices below the maximum legal price. This will lead him to set different prices according to the freight transported and the degree of competition. Consequently, railway tracks are in the situation of collective industries because they can go bankrupt (see section II-3). As a result, government intervention is not required.

In brief, the State should operate railway lines in the case of no intermodal competition and no intramodal competition (passengers and perishable freight), whereas its interven- 
tion is not required for railway tracks where there is competition from either other means of transportation or other railway lines. While Dupuit tackled the issue of mixed railway tracks (transport of passengers and freight) from the point of view of taxation, he did not discuss the most efficient way to manage them. Nevertheless, in "Voies de communication" he concludes that every "transport means that is a monopoly must be operated by the State; every transport means that is accessible to competition must be operated by private industry" (1853a, p. $452) .^{32}$

\section{CONCLUSION}

Beyond the richness of Dupuit's thought, his position on the railroads of the nineteenth century echoes contemporary debates over the introduction of competition in the European railway system. Most of these debates lead to favoring the separation of the railway infrastructure operator from the railway companies; and this is particularly salient if we consider the position of the European Commission (EC, Directive 91/440). However, empirical studies are ambiguous on the results of vertical separation in order to boost competition on the railroads and increase rail transport's market share as compared to cars and airplanes. For instance, some studies (Pedro Cantos et al. 2010; Guido Friebel et al. 2010) reach the conclusion that the effect of vertical separation on costs in Europe is positive. But many others perceive either the absence of correlation between vertical separation and costs (Cantos \& al. 2012; Heinke Wetzel 2008), or a negative correlation (Christian Growitsch \& Heike Wetzel 2009; Anne Jensen \& Petra Stelling 2007). ${ }^{33}$

\footnotetext{
${ }^{32}$ Numa criticizes Ekelund \& Hébert's translation of this sentence in Secret origins of modern microeconomics (1999, p. 324). In their response to Numa, they (2012) claim that "Numa's complaint about our mistranslation is less central to Dupuit's 'ultimate position' than he thinks, but for the record, Numa translated Dupuit correctly...". So I appeal to Numa's translation.

${ }^{33}$ For a survey on the empirical studies regarding the effects of vertical separation in the railway sector, see Fumitoshi Mizutani \& Shuji Uranishi (2012) and van de Velde (2012).
} 
Perhaps one lesson could be drawn from Dupuit: there is no "one-size-fits-all" solution for all rail transport systems in Europe. This is in line with the position of Guido Friebel et al. (2007) and Russell Pittman (2005): for instance, the latter claims that "the model [vertical separation] has not always worked out as well in practice as it has on the blackboard. In recent years it has become apparent that the model is more likely to be successful in some sectors than in others, and in some countries at some times than in other countries at other times" (Pittman 2005, p. 181).

More generally, it is also interesting to note that the issue of the railroads is representative of how Dupuit considered the function of government in society. In line with the French liberals of the nineteenth century, he argued that the optimal solution is unlimited competition. However, unlike them, he considered that State intervention is necessary to increase the welfare of the nation. This is typically the case for property rights, for instance, where Dupuit distinguished between land property and intellectual property rights. While property rights over land should be individual, intellectual property rights should be managed by the State: his rationale consisted in stating again the superiority of unlimited competition, and then stressing the special features of intellectual property rights which lead him to defend State intervention for intellectual works (pictures, books, etc.) and inventions. He offers two arguments as to why individual appropriation of land is better than collective appropriation: first, agricultural output is higher for the former than for the latter, since it stimulates self-interest; second, individual propriety rights over land increases the intellectual satisfaction of the property owner and his sense of responsibility (Dupuit 1861c, pp. 611-2). Thus, he considered that, unlike land, intellectual works and inventions demonstrate the characteristics of what modern economists refer to as public goods: thus, Government intervention is required. In Dupuit's opinion, the optimum solution would consist in passing works into the public domain, but there would be no incentive to create and innovate. Copyright and patents are nec- 
essary to give creators and innovators an incentive. As with the railroads, Dupuit distinguished between the case of literary and artistic works and inventions: the duration of copyrights should be lower than that of patents because invention is a cumulative process $(1861 \mathrm{~b}$, pp. 629-30). Moreover, Dupuit claimed that the duration of patents should depend on the sector and should vary according to time and space (Ibid., pp. 632-3).

Thus, according to Dupuit, it is impossible to assert unequivocally that a sector should be operated by the State. The scope of government intervention should be determined according to the criterion of "public utility". The economist has to look at the conditions of society, which means that the solution depends on the technological, social and economic conditions of society and on the characteristics of the goods. 


\section{REFERENCES}

Allais, Maurice. 1989. La théorie générale des surplus (2nd ed.). Grenoble: Presses Universitaires de Grenoble.

Béraud, Alain. 2005a. "Le marché, les services publics et les monopoles." Actes du 4ème Colloque de l'Association internationale Walras, Les Cahiers du CERAS (4): 25-51. Available at: http://halshs.archives-

ouver-

tes.fr/docs/00/03/72/35/PDF/Le_marche_les_services_publics_et_les_monopoles.pdf: 128.

Béraud, Alain. 2005b. "Richesse et Valeur: la contribution des économistes français du début du 19éme siècle.” Economies et Sociétés, Cahiers de l'ISMEA, PE (36): 1009-32.

Available at:

http://halshs.archives-ouvertes.fr/docs/00/05/40/65/PDF/valeur_et_richesse_3.pdf:100932.

Blaise, Adolphe. 1862. “Correspondance - Les chemins de fer et l'Etat - Lettre au Rédacteur en chef." Journal Des Économistes (JDE) 33(28): 280-2.

Breton, Yves, \& Klotz, Gérard. (eds.). 2009. Jules Dupuit - Euvres Economiques Complètes. Paris: Economica.

Cantos, Pedro \& Pastor, José Manuel \& Serrano, Lorenzo. 2010. "Vertical and horizontal separation in the European railway sector and its effects on productivity." Journal of Transport Economics and Policy 44 (2): 139-60.

Cantos, Pedro \& Pastor, José Manuel \& Serrano, Lorenzo. 2012. "Evaluating European railway deregulation using different approaches." Transport Policy 24: 67-72.

Caron, François. 1997. Histoire des chemins de fer en France. I: 1740-1833. Paris: Fayard.

Colson, Clément. 1908. Transports \& Tarifs. (3rd ed.). Paris: Lucien Laveur. 
Daniel, Norman E. 1971. "The Impact of Ellet, Dupuit, and Lardner on the Development of Economic Concepts." Nebraska Journal of Economics and Business 10(2): 35-54.

Diemer, Arnaud. 2000. "Jules Dupuit et la discrimination par les prix." In Les traditions économiques françaises: 1848-1939, edited by P. Dockès, L. Frobert, G. Klotz, J.-P. Potier, \& A. Tiran: 337-49. CNRS Editions.

Diemer, Arnaud. 2003. "Utilité, valeur, demande, la controverse entre Jean-Baptiste Say et Jules Dupuit." In Jean-Baptiste Say: nouveaux regards sur son æeuvre, edited by J.-P. Potier \& A. Tiran: 361-80. Economica.

Dupuit, Jules. 1844 [1952]. “De la mesure de l'utilité des travaux publics.” English translation by R. H. Barback 1952. On the measurement of the utility of public works. International Economic Papers, 2: 83-110.

Dupuit, Jules. 1849 [1962]. "De l'influence des péages sur l'utilité des voies de communication." English translation by E. Henderson 1962. On Tolls and Transport Charges. International Economic Papers, 11: 7-31.

Dupuit, Jules. 1852. “Eau.” Dictionnaire de l'Économie Politique (DEP), reproduced in Breton \& Klotz (eds.) 2009, I: 535-59.

Dupuit, Jules. 1853a. "Voies de communication." DEP, reproduced in Breton \& Klotz (eds.) 2009, I: 431-52.

Dupuit, Jules. 1853b. "Péage.” DEP, reproduced in Breton \& Klotz (eds.) 2009, I: 517-29.

Dupuit, Jules. 1853c. "Du monopole des chemins de fer." JDE, intervention at Société $d^{\prime}$ Économie Politique (SEP), meeting of March, $10^{\text {th }} 1853$; reproduced in Breton \& Klotz (eds.) 2009, I: 573-5.

Dupuit, Jules. 1853d. "Routes et chemins.” DEP, reproduced in Breton \& Klotz (eds.) 2009, I: 453-66. 
Dupuit, Jules. 1861a. "Voies de communication." Dictionnaire universel théorique et pratique du commerce et de la navigation, reproduced in Breton \& Klotz (eds.) 2009, I: 46776.

Dupuit, Jules. 1861b. “Du principe de propriété. Le juste - L'utile (suite et fin).” JDE, reproduced in Breton \& Klotz (eds.) 2009, II: 613-40.

Dupuit, Jules. 1861c. “Du principe de propriété. Le juste - L'utile.” JDE, reproduced in Breton \& Klotz (eds.) 2009, II: 583-612.

Dupuit, Jules. 1862a. “Les compagnies son-elles plus aptes que l'Etat à exercer une industrie, surtout lorsque cette industrie est un monopole? S'il y a possibilité de concilier les grandes compagnies avec la concurrence." JDE, intervention at $S E P$, meeting of December, $5^{\text {th }} 1861$; reproduced in Breton \& Klotz (eds.) 2009, I: 583-9.

Dupuit, Jules. 1862b. “[Monsieur le Rédacteur, Mon honorable collègue, M. Blaise (des Vosges)].” February, 28 $8^{\text {th }} 1862$; reproduced in Breton \& Klotz (eds.) 2009, I: 591-7.

Dupuit, Jules. 1863a. “Chemin de fer.” In M. Block (Ed.), Dictionnaire général de la politique, reproduced in Breton \& Klotz (eds.) 2009, I: 477-89.

Dupuit, Jules. 1863b. “Questions d'économie politique et de droit public par M. G. de Molinari." JDE, reproduced in Breton \& Klotz (eds.) 2009, II: 125-32.

Dupuit, Jules. 1865. "Suppression des droits de navigation sur les canaux et amélioration des voies navigables." JDE, intervention at $S E P$, meeting of February, $6^{\text {th }} 1865$; reproduced in Breton \& Klotz (eds.) 2009, I: 531-4.

Ekelund, Robert B. \& Hébert, Robert F. 1999. Secret origins of modern microeconomics. Dupuit and the engineers. Chicago: University of Chicago Press.

Ekelund, Robert B. \& Hébert, Robert F. 2002. “The Origins of Neoclassical Microeconomics." Journal of Economic Perspectives 16(3): 197-215. 
Ekelund, Robert B. \& Hébert, Robert F. 2003. "Ethics, Engineering, and Natural Monopoly: The 'Modern Debate' between Léon Walras and Jules Dupuit." History of Political Economy 35(4): $655-78$.

Ekelund, Robert B. \& Hébert, Robert F. 2012. "Dupuit and the railroads.” History of Political Economy 44(1): 97-111.

Ekelund, Robert B. 1970. "Price Discrimination and Product Differentiation in Economic Theory: An Early Analysis.” The Quarterly Journal of Economics 84(2): 268-78.

Ekelund, Robert B. 2008. "Dupuit, Arsene-Jules-Emile Juvenal (1804-1866)." In The New Palgrave Dictionary of Economics, edited by S. N. Durlauf \& L. E. Blume, $2^{\text {nd }}$ edition: 561-63. Basingstoke: Nature Publishing Group.

Ekelund, Robert B. \& Gramm, William P. 1970. "Early French Contributions to Marshallian Demand Theory." Southern Economic Journal 36(3): 277-86.

Ekelund, Robert B., \& Shieh, Yeung-Nan. 1986. "Dupuit, Spatial Economics and Optimal Resource Allocation: A French Tradition.” Economica, New Series 53(212): 483-96.

Etner, François. 1987. Histoire du calcul économique en France. Paris: Economica.

European Commission. 1991. Directive 91/440, Official Journal 24th August 1991; http://www.rff.fr/biblio \_pdf/eur\_ref \_direct\_eu\91\440\_CEE.pdf

Friebel, Guido \& Guriev, Sergei \& Pittman, Russell \& Shevyakhova, Elizaveta \& Tomova, Anna. 2007. "Railroad Restructuring in Russia and Central and Eastern Europe: One Solution for All Problems?" Transport Reviews 27(3): 251-71.

Friebel, Guido \& Ivaldi, Marc \& Vibes Catherine. 2010. "Railway (De)Regulation: A European Efficiency Comparison.” Economica 77(305): 77-91.

Grall, Bernard. 2004. Economie des forces et production d'utilité. La pensée gestionnaire des ingénieurs des ponts (1831-1891). Rennes: Presses Universitaire de Rennes. 
Growitsch, Christian \& Wetzel, Heike. 2009. "Testing for economies of scope in European Railways: an efficiency analysis." Journal of Transport Economics and Policy 43 (1): 124.

Houghton, R. W. 1958. “A Note on the Early History of Consumer's Surplus.” Economica, New Series 25(97): 49-57.

Jensen, Anne \& Stelling, Petra. 2007. "Economic impacts of Swedish rail way deregulation: A longitudinal study." Transportation Research Part E 43(5): 516-34.

Léon, Pierre. 1976. "La conquête de l'espace national." In Braudel Fernand (ed.). Histoire économique et sociale de la France. (first ed.) t. 3, vol. I : 1789-1880, pp. 241-273. Paris: PUF.

Levasseur, Emile. 1912. Histoire du commerce de la France. Paris: Arthur Rousseau.

Mizutani, Fumitoshi \& Uranishi, Shuji. 2012. "Does vertical separation reduce cost? An empirical analysis of the rail industry in European and East Asian OECD Countries." Journal of Regulatory Economics, DOI 10.1007/s11149-012-9193-4.

Mosca, Manuela. 1998. “Jules Dupuit, the French ‘ingénieurs économistes’ and the Société d'Economie Politique." In Studies in the History of French Political Economy, edited by G. Faccarello: 254-83. Londres: Routledge.

Mosca, Manuela. 2008. "On the origins of the concept of natural monopoly: Economies of scale and competition." The European Journal of the History of Economic Thought 15(2): $317-53$.

Numa, Guy. 2009a. “Théorie de l'agence et concessions de chemins de fer français au 19ème siècle." Revue d'économie industrielle (125): 105-28.

Numa, Guy. 2009b. Réglementations et concurrence dans les chemins de fer français (18231914). PhD diss., University of Paris-Dauphine. 
Numa, Guy. 2012. "Dupuit and Walras on the Natural Monopoly in Transport Industries: What They Really Wrote and Meant", History of Political Economy 44(1), 2012: 69-95.

Numa, Guy. 2011. "On the origins of vertical unbundling: The case of the French transportation industry in the nineteenth century". The European Journal of the History of Economic Thought, DOI:10.1080/09672567.2011.565354.

Pfouts, Ralph W. 1953. "A Critique of Some Recent Contributions to the Theory of Consumers' Surplus." Southern Economic Journal 19(3): 315-33.

Picard, Alfred. 1887. Traité des chemins de fer. I. Paris: Rothschild Editeur.

Pittman, Russell. 2005. "Structural Separation to Create Competition? The Case of Freight Railways." Review of Network Economics 4(3): 181-96.

Poinsot, Philippe. 2010. “The foundations of justice in Jules Dupuit's thought." The European Journal of the History of Economic Thought 17(4): 793-812.

Poinsot, Philippe. 2011. La relecture de l'œuvre de Jules Dupuit à l'aune de la notion de bien-être: intérêt général, bien-être et utilité publique. $\mathrm{PhD}$ diss., University of Paris 1 Panthéon-Sorbonne.

Ribeill, Georges. 1997. 'Le principe du 'libre parcours' sur les premiers chemins de fer concédés français. Fondements théoriques et obstacles pratiques." Revue d'histoire des chemins de fer (16-17): 29-46.

Siroën, Jean-Marc. 1995. "Dupuit et la pensée économique contemporaine.” Revue française d'économie 10(2): 35-54.

Smith, Cecil O. 1990. The longest run: Public engineers and planning in France. The American Historical Review, 95(3): 657-92.

Stigler, George J. 1950. “The Development of Utility Theory. I." The Journal of Political Economy 58(4): 307-27. 
van de Velde, Didier \& Nash, Chris \& Smith, Andrew \& Mizutani, Fumitoshi \& Uranishi, Shuji \& Lijesen, Mark \& Zschoche, Frank. 2012. EVES-Rail - Economic effects of Vertical Separation in the railway sector; Full technical report for CER - Community of European Railways and Infrastructure Companies; by inno-V (Amsterdam) in cooperation with University of Leeds - ITS, Kobe University, VU Amsterdam University and cavity management consultants.

Wetzel, Heinke. 2008. "European Railway Deregulation." Working Paper 86, Institute of Economics, Leuphana University of Luneburg.

http://ideas.repec.org/p/lue/wpaper/86.html 